\title{
AKTIVITAS ANTIBAKTERI DARI DESAIN MIKROEMULSI MINYAK ATSIRI KAYU MANIS
}

\author{
Evelyn Djiuardi ${ }^{1)}$, Tutun Nugraha ${ }^{2)}$ \\ ${ }^{1}$ Universitas Trilogi, Program Studi Ilmu dan Teknologi Pangan, Fakultas Bioindustri \\ ${ }^{2}$ Universitas Surya, Program Studi Teknik Lingkungan, Fakultas Clean Energy and Climate \\ Change \\ evelyn.djiuardi@ trilogi.ac.id
}

\begin{abstract}
This research focused on the study of the capability of cinnamon essential oil as antibacterial agent, when it is made as a microemulsion solution. The study occupied further research on specific type, concentration, and amount of emulsifier needed to make the cinnamon essential oil miscible in water without causing destruction in its antibacterial activity. Four different emulsifiers were tested, namely Tween 20, Tween 80, soya lechitin, and carboxymethyl cellulose $(C M C)$ to stabilize the essential oil in water. The emulsifiers were used at $2 \% \mathrm{w} / \mathrm{w}$, while the essential oil concentrations were varied at $0.5 \%, 1 \%$, and $1.5 \%$. In this study, the antibacterial activity of the microemulsion solution of cinnamon essential oil was tested against two types of pathogenic bacteria commonly found in foods, namely Staphylococcus aureus and Escherichia coli. Among the four types of emulsifiers, which are used, CMC showed the best results as an emulsifier. The results of this study indicated that microemulsion solution has antibacterial activity best is a combination between the CMC and the essential oil of cinnamon.
\end{abstract}

Keywords: microemulsion, antibacterial, cinnamon, essential oil

\section{PENDAHULUAN}

Saat ini masyarakat tampaknya mengalami tren "konsumerisme hijau", yang menginginkan bahan tambahan makanan yang mengandung sedikit bahan sintetis dan produk dengan dampak yang lebih kecil terhadap lingkungan. Oleh karena itu, pengembangan senyawa antibakteri dari minyak atsiri menunjukkan peningkatan baik dari para peneliti maupun industri pangan. Selain itu, minyak atsiri dikembangkan untuk menjadi alternatif bahan pengawet pangan. Pada umumnya, masyarakat menggunakan minyak atsiri dari rempah - rempah hanya sebagai penyedap makanan dan minuman, namun sekarang ini banyak penelitian untuk mengembangkan minyak atsiri karena sudah sejak lama diketahui bahwa minyak atsiri memiliki sifat antibakteri dan antimikroba. (Rasooli 2007)

Meskipun rempah - rempah dan tanaman herbal aromatik biasanya digunakan untuk menguatkan rasa masakan, tetapi rempah - rempah dan tanaman herbal aromatik dapat dipergunakan sebagai senyawa pengawet makanan karena memiliki aktivitas antibakteri. (Prabuseenivasan et al. 2006, Rasooli 2007, Santas et al. 2010, Ebrahimi et al. 2013, Djenane et al. 2013). Pada saat ini, konsumen cenderung lebih peduli terhadap kesehatan, sehingga konsumen menginginkan produk pangan yang mengandung sedikit zat pengawet makanan sintetik dan produk yang tidak mencemari lingkungan. Maka dari itu, senyawa antibakteri dari minyak atsiri menjadi topik yang cukup diminati oleh para peneliti maupun pelaku industri pangan.

Dalam proses pengawetan makanan, kebutuhan yang paling utama adalah perpanjangan umur simpan dari produk pangan agar proses pengawetan dapat ditingkatkan secara maksimal. Melalui proses pengawetan makanan, jumlah mikroorganisme patogen yang dapat menyebabkan kerusakan produk pangan ditekan seminimal mungkin. Ada beberapa sistem pengawetan bahan pangan yang dapat dipergunakan untuk menurunkan resiko wabah keracunan makanan, misalnya proses pemanasan, proses pembekuan dan 
penambahan senyawa antimikroba (Rasooli, 2007). Untuk memperpanjang umur simpan, industri bahan pangan banyak menggunakan bahan kimia sebagai zat pengawet makanan untuk menurunkan jumlah mikroorganisme patogen. Namun pada saat ini konsumen memiliki kepedulian yang tinggi terkait keamanan bahan pengawet makanan dari zat kimia. Industri bahan pangan didorong untuk mengeksplorasi lebih jauh mengenai penggunaan bahan - bahan alami yang terdapat di alam sebagai zat pengawet alami. (Santas et al. 2010; Ebrahimi et al. 2013; Djenane et al. 2013). Oleh karena itu, ada peningkatan penelitian dalam eksplorasi senyawa alternatif yang dapat digunakan secara efisien sebagai bahan pengawet makanan. Penggunaan senyawa alternatif alami dimaksudkan untuk mengganti sebagian atau bahkan dapat mengganti secara keseluruhan penggunaan bahan tambahan pengawet yang dibuat bahan kimia.

Perbedaan utama dari penelitian penelitian minyak atsiri terdahulu adalah di dalam penelitian ini, aktivitas antimikroba dari minyak atsiri kayu manis akan ditingkatkan dengan desain mikroemulsi. Minyak atsiri kayu manis diperunakan sebagai bahan pengawet makanan alternatif. Minyak atsiri kayu manis memiliki aktivitas antibakteri yang tinggi karena mengandung senyawa aktif eugenol, cinnamamicaldehyde, dan citral. (Rasooli 2007). Kayu manis adalah bahan pengawet alami dan zat penyedap yang tidak berbahaya untuk dikonsumsi. Pada penelitian ini, minyak atsiri kayu manis dikombinasikan dengan beberapa jenis emulsifier. Kombinasi minyak atsiri dan emulsifier yang memberikan hasil paling baik dapat dipergunakan sebagai alternatif bahan pengawet alami makanan.

\section{METODE}

\section{Bahan}

Bahan utama yang digunakan dalam penelitian ini adalah minyak atsiri kayu manis yang diperoleh dari kulit pohon Cinnamomum burmanii. Minyak atsiri diperoleh dengan menggunakan teknik destilasi uap. Bakteri patogen yang dipergunakan adalah Staphylococcus aureus dan Escherichia coli. Dalam penelitian ini, ada 4 tipe emulsifier yang dipergunakan, yakni Soya Lecithin, Carboxymethyl Cellulose (CMC), Tween 80 dan Tween 20. Larutan mikroemulsi dibuat menggunakan high shear mixer.

\section{Metode Pengujian Sifat Antibakteri Dalam Fase Cair dengan Desain Mikroemulsi}

Sifat antibakteri dari minyak atsiri kayu manis dalam fase cair diteliti dengan menggunakan metode Disc Diffusion. Dalam penelitian ini, tipe media kultur yang dipergunakan Mueller - Hinton Agar. Dalam setiap petri dish, ditempatkan 4 kertas cakram di permukaan Mueller - Hinton Agar. 3 kertas cakram mengandung ekstrak dari emulsifier dengan beberapa konsentrasi dan 1 kertas cakram mengandung Dimethylsulfoxide (DMSO) sebagai kontrol negatif. Berdasarkan literatur Performance Standards for Antimicrobial Susceptibility Testing (2014), setelah 16 - 18 jam inkubasi, setiap petri dish diamati. Apabila petri dish sudah diinokulasi, zona inhibitor akan terbentuk di sekitar kertas cakram. Selanjutnya diameter zona inhibitor diukur dengan menggunakan Vernier Caliper.

\section{HASIL DAN PEMBAHASAN}

\section{Penelitian Pendahuluan}

Tujuan dari penelitian pendahuluan adalah untuk mencari metode terbaik untuk meningkatkan aktivitas antibakteri dari minyak atsiri kayu manis dengan menggunakan desain mikroemulsi. Penelitian ini terdiri dari tahap penentuan formulasi larutan mikroemulsi, tahap mempelajari teknik transfer aseptik, tahap pemindahan inokulan, dan tahap mempelajari teknik pengujian aktivitas antibakteri. Sebelum melanjutkan ke penelitian utama, larutan mikroemulsi yang stabil harus dibuat. Secara umum, untuk membuat campuran yang stabil dari 2 cairan yang tidak bisa menyatu (minyak dan air) diperlukan zat emulsifier. Penambahan zat emulsifier dan penggunaan high shear mixer akan membuat larutan emulsi stabil.

Senyawa emulsifier akan mencegah butiran minyak atau lemak terpisah dari cairan pelarutnya. Schubert et al. (2006) menyimpulkan bahwa emulsi yang memiliki ukuran partikel yang sangat kecil dan 
menggunakan senyawa emulsifier yang tepat akan menghasilkan larutan emulsi yang stabil. Oleh karena itu, pada penelitian ini, 4 jenis emulsifier yang berbeda digunakan dengan tujuan untuk mencari jenis emulsifier yang dapat menghasilkan larutan emulsi paling stabil namun larutan emulsifier tersebut tetap memiliki stabilitas fisik yang baik. Setiap jenis emulsifier memiliki sifat kimia yang berbeda. Perbedaan sifat yang paling mencolok adalah nilai viskositas yang dimiliki oleh setiap emulsifier. Carboxymethyl Cellulose (CMC) memiliki nilai viskositas yang paling tinggi diantara 4 jenis emulsifier. Meskipun demikian, CMC banyak digunakan sebagai emulsifier karena bersifat tidak beracun, tidak menyebabkan alergi dan dapat memperbaiki tekstur makanan. Maka dari itu, CMC diharapkan dapat memberikan hasil yang terbaik di antara 4 jenis emulsifier. Pada proses pembuatan larutan mikroemulsi, senyawa emulsifier memiliki dua fungsi, yaitu melapisi partikel minyak dan menurunkan tegangan permukaan air sehingga air dan minyak bisa bercampur sempurna.

Penelitian pendahuluan menghasilkan keputusan metode yang paling tepat untuk dipergunakan dalam penelitian utama. Sedangkan uji aktivitas antibakteri menghasilkan kesimpulan sebagai berikut :1)Escherichia coli dipilih sebagai perwakilan dari bakteri Gram - negatif dan Staphylococcus aureus dipilih sebagai perwakilan dari bakteri Gram - positif. Kedua bakteri ini dipilih karena kedua jenis bakteri ini mewakili bakteri patogen pada makanan, 2) DimethylSulfoxide (DMSO) dipergunakan sebagai kontrol negatif dan tidak memiliki aktivitas antibakteri, 3) emulsifier tidak memiliki aktivitas antibakteri, 4) kertas cakram $6 \mathrm{~mm}$ hanya dapat menyerap maksimal $10 \mu \mathrm{L}$ larutan, 5) Kertas cakram harus digunakan karena apabila larutan mikroemulsi diteteskan langsung ke atas media, zona inhibitor yang terbentuk tidak jelas sehingga tidak dapat diukur diameternya 6) Proses inkubasi selama 48 jam tidak menimbulkan perubahan ukuran diameter zona inhibitor.

\section{Penelitian Utama}

Penelitian utama dalam penelitian ini adalah pengujian aktivitas antibakteri dari desain mikroemulsi minyak atsiri kayu manis terhadap dua jenis bakteri, yakni bakteri gram negatif dan bakteri gram positif. Menurut Gupta et al. (2008), media yang lain yang dapat dipergunakan dalam metode disc diffusion adalah kertas cakram dan turbiditas standar dari inokulum yang digunakan adalah $10^{6} \mathrm{CFU} / \mathrm{ml}$. Dalam setiap cawan Petri dish, 4 kertas cakram ditempatkan di atas Mueller Hinton Agar, 3 kertas cakram mengandung ekstrak larutan emulsi yang menggunakan jenis emulsifier yang sama namun memiliki konsentrai minyak atsiri yang berbeda dan 1 kertas cakram mengandung Dimethylsulfoxide (DMSO) sebagai kontrol negatif.

Penelitian diulangi untuk mengumpulkan 4 data yang diperlukan untuk analisis statistik. Menurut Lalitha (2004), kertas cakram yang dipergunakan harus diletakan secara berjauhan satu sama lain. Jarak minimum antar kertas cakram adalah $24 \mathrm{~mm}$. Berdasarkan penelitian dari Performance Standards for Antimicrobial Susceptibility Testing (2014), setelah inkubasi setelah 16 sampai dengan 18 jam, setiap cawan diobservasi. Apabila larutan mikroemulsi tersebut mengandung aktivitas antibakteri, maka akan dihasilkan zona inhibitor di sekitar kertas cakram. Hal ini membuktikan bahwa larutan mikroemulsi dapat menghambat pertumbuhan bakteri. Diameter zona inhibitor yang menandakan aktivitas antibakteri diukur dengan menggunakan Vernier Caliper. Kemudian data yang diperoleh dianalisis dengan menggunakan Microsoft Excel 2007.

Pada penelitian utama ini, diperoleh hasil bahwa minyak atsiri kayu manis memiliki aktivitas antibakteri. Aktivitas antibakteri dalam fase cair untuk S.Aureus dan E. Coli ditunjukkan pada grafik 1 dan grafik 2 di bawah ini. Pada penelitian ini, aktivitas antibakteri dari minyak atsiri kayu manis dimulai pada konsentrasi $0.5 \%$ dan terus meningkat hingga konsentrasi $1.5 \%$ dalam $150 \mathrm{~mL}$ larutan emulsi. 


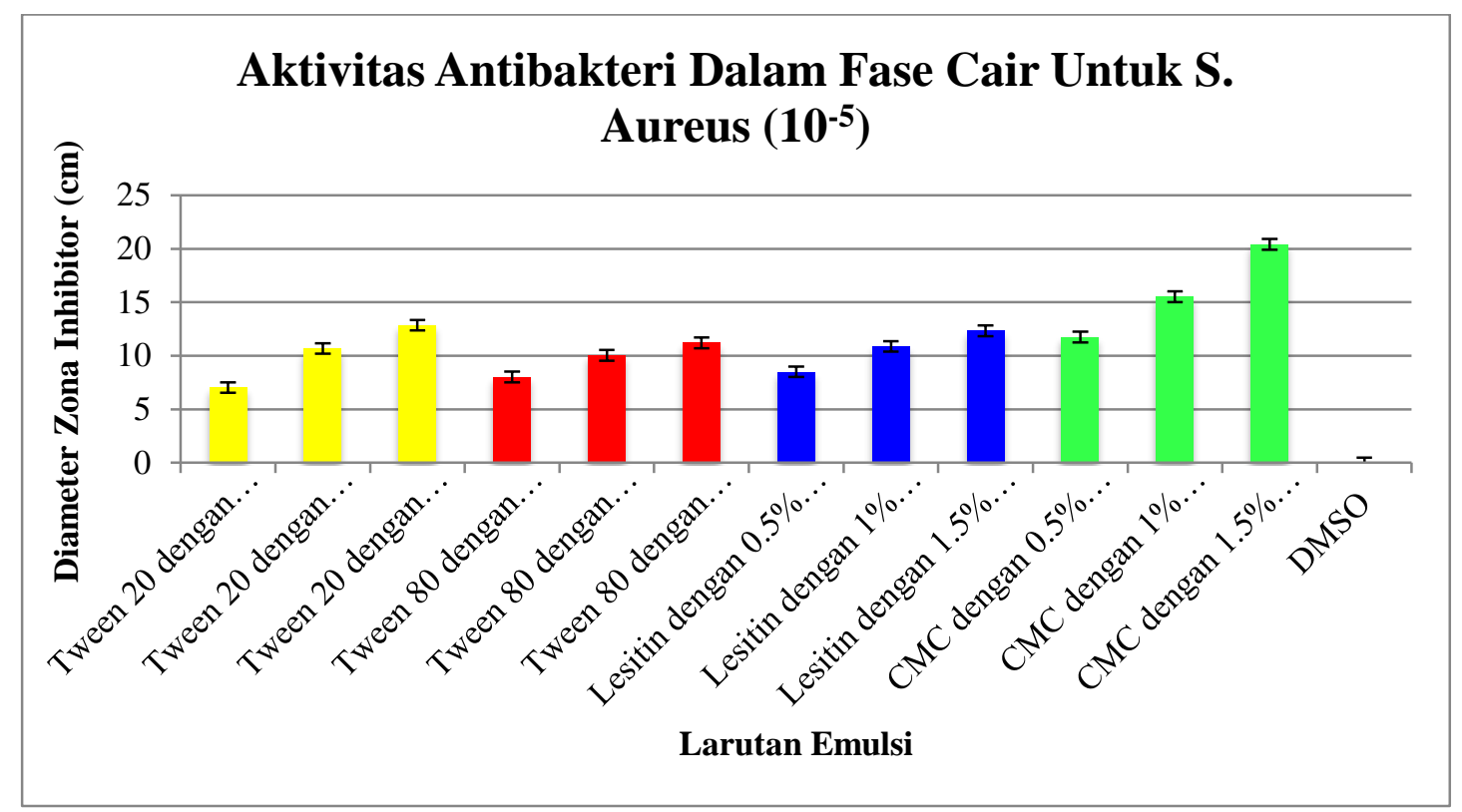

Gambar 1. Hasil Aktivitas Antibakteri dalam Fase Cair untuk S.Aureus $\left(10^{-5}\right)$

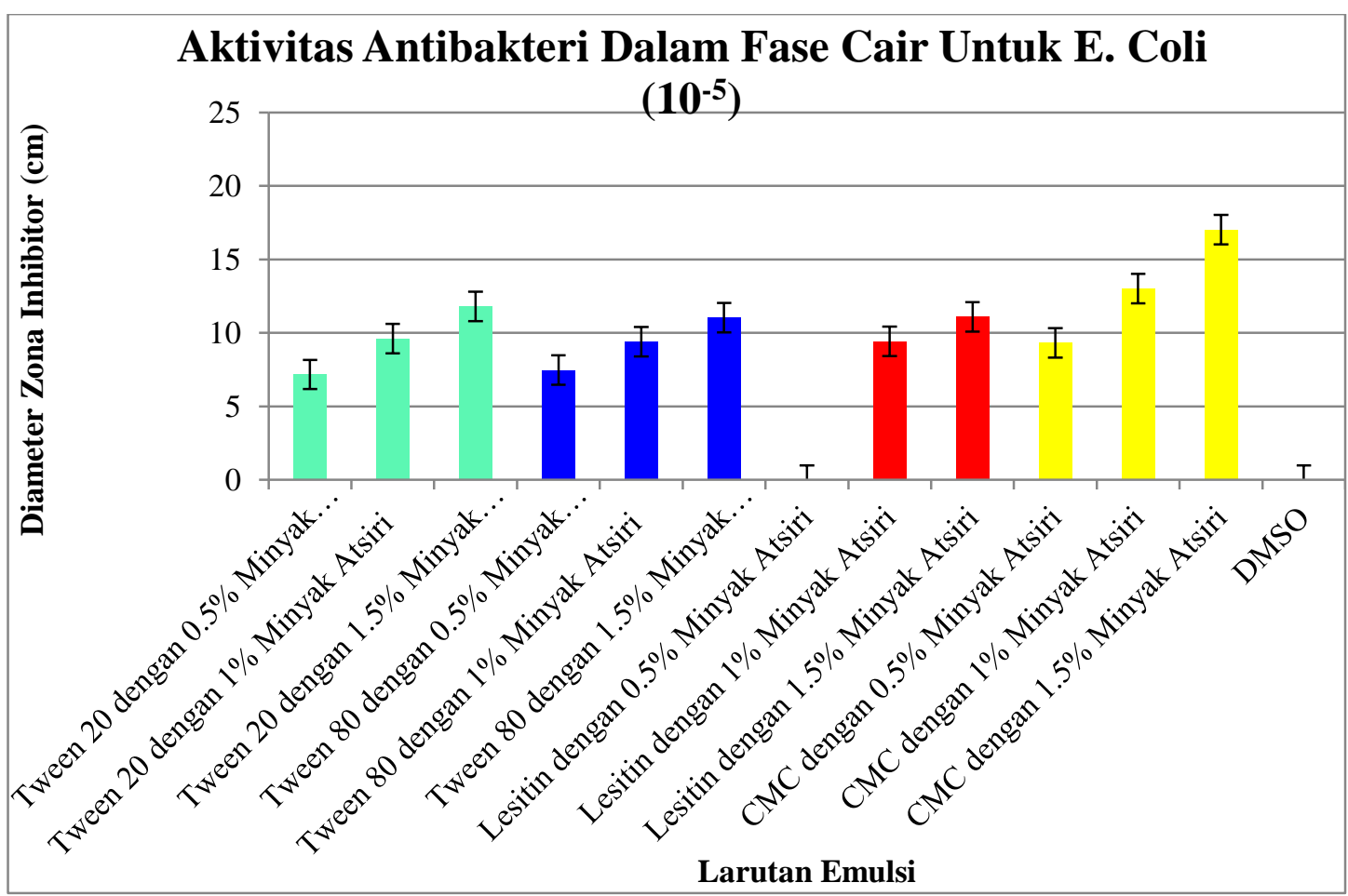

Gambar 2. Hasil Aktivitas Antibakteri dalam Fase Cair untuk E.Coli $\left(10^{-5}\right)$

Dari Gambar 1 dan Gambar 2 di atas, dapat dilihat bahwa aktivitas antibakteri yang tertinggi ditunjukkan oleh larutan emulsi yang menggunakan jenis emulsifier CMC. Selain itu dapat dilihat pula bahwa DMSO yang dipergunakan sebagai kontrol negatif tidak memiliki aktivitas antibakteri. Analisis statistik $\mathrm{t}-$ Test digunakan untuk membandingkan diameter zona inhibitor pertumbuhan E. Coli dan S. Aureus pada konsentrasi $10^{-5}$. Perbedaan diameter zona inhibitor berbeda nyata secara statistik ( $\mathrm{p}<$ 0.05 ) yang menunjukkan bahwa minyak atsiri kayu manis lebih efektif dalam menghambat pertumbuhan S.Aureus (Gram positif) dibandingkan E.Coli (Gram negatif). Hal ini 
disebabkan karena adanya dinding sel ganda yang dimiliki oleh bakteri gram negatif. (Raven et al. 2001; Chatterjee 2012). Dinding sel ganda ini mencegah difusi senyawa hidrofobik seperti minyak atsiri kayu manis melalui lapisan lipopolisakarida. Hidrofobisitas dari minyak atsiri dapat memecah lipid pada membran sel bakteri, merusak struktur membran sehingga menyebabkan kebocoran membran sel dan pada akhirnya menyebabkan sel bakteri mati (Burt 2004). Bakteri gram positif, yakni Staphylococcus Aureus tidak memiliki membran luar sel, sehingga lebih sensitif terhadap aktivitas antibakteri dari minyak atsiri.

Selain karena bakteri E.Coli memiliki dinding sel ganda, sifat dari bakteri E.Coli yang tahan terhadap asam juga membuat bakteri tersebut lebih tahan terhadap aktivitas antibakteri di dalam minyak atsiri kayu manis. Pada minyak atsiri kayu manis terdapat senyawa aktif yang memiliki aktivitas antibakteri yakni eugenol. Menurut Burt (2004), mekanisme aksi dari senyawa fenolik seperti eugenol adalah mengganggu fungsi membran sitoplasma, transpor aktif, aliran elektron di dalam sel, dan pembekuan isi sel. Eugenol merupakan senyawa asam dan bakteri Eschericia coli merupakan bakteri yang tahan terhadap asam (Stincone et al. 2011). Menurut Madigan (2006) dan Stincone et al. (2011), E.Coli merupakah salah satu contoh dari bakteri enterik. Untuk berkoloni dan menyebabkan penyakit, bakteri enterik harus menghadapi tantangan dari lingkungan yang termasuk asam yang tinggi yang terdapat di dalam perut dan usus manusia. Maka dari itu, dalam penelitian ini bakteri E.Coli lebih tahan terhadap aktivitas antibakteri minyak atsiri kayu manis karena bakteri E.Coli dapat bertahan terhadap aktivitas eugenol.

Dari keempat jenis emulsifier yang dipergunakan, kombinasi antara CMC dan minyak atsiri kayu manis menghasilkan hasil yang terbaik dalam menghambat aktivitas bakteri, baik bakteri gram positif maupun bakteri gram negatif. Hal ini disebabkan karena kemampuan dari CMC untuk bertindak sebagai lapisan pelindung dari minyak atsiri kayu manis dan membentuk larutan mikroemulsi yang stabil dan baik sehingga air dan minyak atsiri kayu manis dapat bercampur dengan sempurna (Hayati et al. 2009), sehingga setelah melalui proses pencampuran dengan menggunakan high shear mixer, larutan mikroemulsi minyak atsiri kayu manis yang dicampur dengan CMC tidak rusak meskipun telah terpapar panas akibat pencampuran dengan kecepatan yang tinggi. Hal ini disebabkan karena partikel minyak atsiri kayu manis terlindungi dengan baik oleh CMC.

\section{KESIMPULAN}

Ekstrak dari batang kayu manis (Cinnamomum burmanii) diketahui memiliki sifat antibakteri. Berdasarkan hasil GCMS, minyak atsiri kayu manis yang dipergunakan pada penelitian ini mengandung eugenol dan cinnamaldehyde. Kedua senyawa tersebut memilki sifat antibakteri yang kuat. Minyak atsiri kayu manis menunjukan aktivitas penghambatan pertumbuhan yang lebih efektif pada Staphylococcus aureus (Gram-positif) dibandingkan terhadap Escherichia coli (Gram-negatif).

Pada penelitian ini, digunakan 4 jenis emulsifier yang berbeda, yaitu Tween 20, Tween 80, Lesitin dan Carboxymethyl Cellulose (CMC). Konsentrasi emulsifier yang dipergunakan adalah 2\% sedangkan konsentrasi minyak atsiri kayu manis yang digunakan bervariasi antara $0.5 \%, 1 \%$, dan 1.5\%. Di antara keempat jenis emulsifier tersebut, CMC menunjukan hasil yang terbaik sebagai emulsifier karena CMC memiliki kemampuan untuk bertindak sebagai lapisan pelindung dari minyak atsiri kayu manis dan membentuk larutan mikroemulsi yang stabil dan baik sehingga air dan minyak atsiri kayu manis dapat bercampur dengan sempurna. Larutan mikroemulsi dapat menghambat pertumbuhan bakteri patogen karena didorong untuk bersatu dengan organisme yang mengandung lipid. Persatuan ini diperkuat dengan adanya daya interaksi elektrostatik antara muatan kation dari emulsi dan muatan anion dari bakteri patogen. Pada saat jumlah partikel mikroemulsi yang bersatu dengan patogen sudah cukup banyak, partikel mikroemulsi akan melepaskan energi dan bahan aktif antibakteri yang ada di dalam partikel sehingga membuat membran lipid tidak stabil dan pada akhirnya mengakibatkan sel lisis dan kematian sel. 


\section{DAFTAR PUSTAKA}

Burt, Sarah., 2004. Essential oils : Their antibacterial properties and potential applications in food - a review. International Journal of Food Microbiology. Volume 4 : 223 - 253.

Chatterjee, S.N., K. Chaudhuri. 2012. Outer Membrane Vesicles of Bacteria. New York : Springer

Djenane D., J. Yangüela, P. Roncales, M. Aider. 2013. Use of Essential Oils as Natural Food Preservatives : Effect on the Growth of Salmonella enteritidis in Liquid Whole Eggs Stored Under Abuse Refrigerated Conditions. Journal of Food Research. Volume 2 : 65 - 78.

Ebrahimi M. dan K.K. Darani. 2013. Essential Oil as natural food preservatives : Antimicrobial and antioxidant applications. Transworld Research Network. Kerala.

Gupta, C., A.P. Garg, R.C. Uniyal, \& A. Kumari. 2008. Comparative Analysis of the Antimicrobial Activity of Cinnamon Oil and Cinnamon Extract on Some Food - Borne Microbes, African Journal of Microbiology Research. Volume 2 : 247 - 251.

Lalitha, M.K. 2004. Manual on Antimicrobial Susceptibility Testing, www.ijmm.org/documents/antimicrobia 1.doc [18 April 2016]

Michigan Nanotechnology Institute for Medicine and Biological Sciences, 2010, Antimicrobial Nanoemulsions.
http://nano.med.umich.edu/platforms/A ntimicrobial-Nanoemulsion.html. [13 Maret 2016].

Mohanka R., dan Priyanka. 2014. Plant Extract As Natural Food Preservative Against Spoilage Fungi From Processed Food, International Journal of Current Microbiology and Applied Science, Volume 3 : 91 - 98.

Prabuseenivasan, S., Jayakumar, M., \& Ignacimuthu, S. (2006). In vitro antibacterial activity of some plant essential oils. BMC Complementary and Alternative Medicine, Volume 6 : 39.

Rasooli, Iraj. 2007. Food Preservation - A Biopreservative Approach, Food, Volume 1, Issue 2 : 111 - 136.

Raven P., G. Johnson, S. Singer, J. Losos, W.C. Ober, \& C. Garrison. 2001. Biology. New York : Mc Graw Hill.

Santas J., M.P. Almajano, R. Carbo. 2010. Antimicrobial and antioxidant activity of crude onion (Allium cepa, L.) extracts. International Journal of Food Science \& Technology. Volume 45, Issue 2 : 403-409.

Stincone, A., Daudi, N., Rahman, A. S., Antczak, P., Henderson, I., Cole, J., Johnson, D.M., Lund, P., Falciani, F. 2011. A systems biology approach sheds new light on Escherichia coli acid resistance. Nucleic Acids Research. Volume 39 (17): 7512-7528 